\title{
COMMUNICATION STRATEGIES' IMPACTS ON THE CONCEPTUALIZATION OF COMMUNICATION MODELS AMONG A SAMPLE OF MILLENNIALS - A PILOT CASE STUDY
}

\author{
[Dopady komunikačních strategií na konceptualizaci osobních komunikačních \\ modelů vybraných mileniálů - pilotní př́ípadová studie]
}

\author{
Dagmar Svobodová ${ }^{1}$ \\ ${ }^{1}$ Slezská univerzita, Obchodně podnikatelská fakulta, Univerzitní nám. 1934/3,733 40 Karviná \\ Email: svobodoval@opf.slu.cz.
}

\begin{abstract}
The goal of the article, to conceptualize the personal communication of a sample of millennials based on their type of communication strategy. It describes the article's theoretical foundation, Berne's communication interconnected with Silsbee's concept of presence. Research methodology presents the mixed research strategy for this gender, implemented as a research pilot case study, and presents the empirical data on assertive presence that was acquired through a questionnaire survey. The results describe of a non-hierarchical cluster analysis from the angle of levels of personal preference for assertive presence in communication among a sample of millennials at Silesian University School of Business Administration (SU SBA) in Karviná studying towards gender in the 2018/2019 school year. They present differing personal communication styles that the selected millennials can apply within self-confident communication strategies.
\end{abstract}

Keywords: communication, conceptualization, millennials, models, strategy.

JEL classification: Z13

Received: 8.9.2020; Reviewed: 10.9.2020; 23.9.2020; Accepted: 16.12 .2020

\section{Introduction}

This article aims to conceptualize the personal communication models of a sample of millennials based on the types of communication strategies they use. We explore the impacts of communication strategies on the conceptualization of the selected millennials' communication models from two standpoints. Firstly, whether and how assertive presence affects selected millennials' psychokinetic anchors within the communication process, and secondly, what communication styles play a part in shaping the designs for the sampled millennials' personal communication models. This article's theoretical foundation comprises the communication model as interpreted by Berne (2016), interconnected with Silsbee's concept of presence (2018). The originality of the researched problem lies in this article we combine attentiveness with Salter's assertiveness principles (2002) as the starting point for a conceptualization of specific types of communication strategies in the framework of sampled millennials' personal communication models. The basic research approach applied in this article is mixed method research approach. Within it, a research pilot case study performed using a qualitative research approach in the form of cluster analysis using quantitative methods assesses and interprets empirical data acquired from a questionnaire survey. In connection with the implementation of the seven voices from Silsbee's concept of presence (2018) into Berne's personal communication models (2016), we predict a differing approach by the sampled millennials towards the application of Salter's assertiveness principles in the sense of assertive presence depending on their type of gender at the Silesian University of Opava School of Business Administration in Karviná (SU SBA). In accord with Schweigert (2012), the hypothesis on a differing approach to the application of assertive presence in personal communication models is operationalized into twelve communication statements, to 
which millennials from four selection subsamples respond in the questionnaire. The benefit is through the shaping of communication integrity, sampled millennials can then more effectively conceptualize personal communication models in their professional careers, and take a more realistic approach within them towards the application of self-confident communication strategies in the job market.

\section{The Communication Model with assertive presence}

Through his communication model (2016), Berne helps every millennial to recognize and understand their own personality. Here it is the psychokinetic anchor that serves as an aid. According to Schmeidler (2015), this anchor reveals a person's authentic psyche. A personal authentic psyche can be understood as one that is original and credible with regard to the diverse personal characteristics of each individual. Here the psychokinetic anchor serves as a tool that influences one's personal communication style. In connection with personal communication style, Berne (2016) distinguishes six personality types that differ based on personal authenticity as the skill of being inwardly authentic or looking outwardly authentic. In Berne's communication model based on personal authentic stances, the skill of being inwardly authentic presumes staying truly and naturally yourself, which is fulfilled by these personality types. The Thinker, who decides based on work quality, categorizes opinions, and is responsible, organized, structural, and precise; they filter information logically and based on the facts. The Imaginer, who lives an internal life and appreciates privacy, but needs autonomy; they are reflective, calm, and introspective, and they filter information through imagination. The Harmonizer, who is empathetic, balanced, and cordial, values friendship, gladly cooperates with others, and filters information through emotions. They use altruistic language. In Berne's communication model, the skill of looking outwardly authentic presumes the ability to convincingly and credibly present authentic stances, which is fulfilled by these personality types. The Persister, who knows how to work under pressure, assesses the world based on their own convictions. They are enthusiastic, principled, avid, conscientious, attentive, and devoted, they appreciate trust and respect other opinions, and they filter information based once again on their own convictions. They are at ease in expressing themselves. The Promoter, who appreciates adaptiveness, convincingness, and performance, is reliable, supportive, charismatic, enterprising, and inventive; they filter information via action. They go straight to the point and know how to present themselves. The Rebel, who is a creative and spontaneous improviser, filters information through reactions to explanations. They appreciate fun, and they have a playful style of communication. When in stress, they react unpredictably and often get out of control. The personality types based on Berne's communication model can be connected with the concept of presence.

Silsbee (2018) places seven voices into this communication model's framework. These are the voices of Master, Partner, Investigator, Reflector, Teacher, Guide, and Contractor. The framework in Silsbee (2018) can place these voices into its concept of presence with a view to the personal communication styles of our sampled millennials, displaying two differing approaches. The first approach is a directive communication style, which is evaluative. This evaluative communication style can be viewed as an authoritarian approach to communication in which the communicator conveys communication skills in the role of patron, applying personal best practices to beginners. An evaluative communication style enables our sample of millennials as beginners to observe more experienced persons, adopt those persons' communication style, and draw closer to goals that are, for them as beginners, only accessible in the long term. Here the Teacher, Contractor, and Guide voices see one-sided overuse. Under the Silsbee model (2018), the Teacher voice offers our sample of millennials, as beginners, new experiences and information, including differentiations of terms. The 
Contractor voice checks the millennials' activities and provides them, as beginners, with feedback on their assigned tasks. The Guide voice guides the millennials, as beginners, through accredited subjects within their gender. However, our sample of millennials, as perceptive beginners who are motivated and goal-oriented, can be communicated with more effectively using a second approach, which is the non-directive style of communication. The non-directive style of communication is non-evaluative. A non-evaluative style of communication can be understood as a democratic approach to communication in which the communicator leans on personal communication resources with the goal of exploring the sampled millennials' possibilities for applying communication strategies in their personal communication models. For this reason, a non-evaluative communication style can be thought of as a relationship within a personal communication model that inspires our sample of millennials to develop their communication potential. These millennials form personal relationships with their communicators via dialogues while taking into account support for personal communication performance. They independently choose communication goals and the means for achieving them. Here the voices of Partner, Investigator, and Reflector see onesided overuse. In the Silsbee model (2018), the Partner voice helps to establish equal relationships for the communicators with our sample of millennials with a view to strengthening personal responsibility, and it works with millennials who, thanks to practical experience, display a high degree of personal and professional maturity. The Investigator voice asks questions in the framework of mutual listening, which presumes a shift from cosmetic listening (where we are listening through one ear with our attention focused on processes around us) on past conversational listening (where we are thinking of what we will say next) and on to active listening (where we understand the perspectives of the sampled millennials with a focus on their information and knowledge). The Reflector voice enables a state of flow, of feeling relaxed, and connecting and tuning in well to the sampled millennials, which presumes being in harmony with them here and now, where new ideas flow optimally, and we are not hurrying anywhere under the pressure of the external environment. There is one voice left, the Master; the millennials in our sample ask this voice: How do you manage to never get thrown off by anything? The Master responds: Oh, I do get thrown off. I just know how to climb right back on.

As these millennials need to apply self-confident communication strategies on the job market during their professional careers, we can recommend integrating Salter's four assertiveness principles (2002) into Silsbee's concept of presence (2018). Salter's assertiveness principles work with perceptiveness both inside of the personalities of the selected millennials, and within their strategies for communicating with other, and they provide the benefits of presence for the development of communication skills. Presence-based assertiveness is characterized by persistence, elegance, clarity, courage, and pragmatism in one's personal communication model. Within the Ames (2008) model, assertiveness can be perceived as a method for appropriate action and behavior that is characterized by honest communication with no need for pressure. Assertiveness emphasizes the millennials' rights, and does not endanger other's rights even when these millennials are in a dominant position. On the other hand, there is no need to act subserviently and let others ignore the opinions of the rest. Assertiveness shows how to respond in situations where the sampled millennials' positions and interests are in conflict with the positions and interests of others. Concerning disagreement, our sampled millennials repeatedly encounter this question: How can I apply assertive presence in the communication process in the course of my professional career? A response to the question posed here can be found in-between the passiveness connected with conflict avoidance and the aggression connected with hostility. Under the Lazarus (2015) model, assertive millennials approach the resolution of their problems constructively. Under 
Wolpe (2012), he can reach for their abilities, which include: expressing their thoughts and feelings clearly and calmly, free, open, and honest communication in all levels and environments while retaining personal self-respect, influencing events in their own professional career, including taking control, and activities in their own name. Under Vymětal (2008), assertiveness supports equality in the communication process, and therefore makes it possible for the sampled millennials to act in their best interest. They can stand up for what is theirs without unneeded anxiety, they can express their true feelings without feeling uneasy, and they can strive for their rights without infringing on the rights of others. Under Smith (2003), assertiveness is the ability to stand up for one's own rights through assertive behavior, on the assumption that partners are communicating on the same level, respect each other and are able to openly express their feelings and thoughts, reject proposals if they disagree with them, express indignation and fear, and be spontaneous without unnecessary fears. Under Lee and Ciftci (2014), assertiveness will be positively associated with academic self-efficacy. Assertive millennials will thus be aware of not only their own rights, but also the rights of others, because they will not take the liberty of offensive and injurious behavior, manipulation, or excessive controlling of others. They differ from other millennials in their ability to utilize the right to evaluate their own behavior, their own thoughts, their own emotions, and their own responsibility for their possible impacts. They display spontaneous emotions, they express their personal viewpoints appropriately, and they come to terms with criticism, including their own mistakes. Newly learned reactions enable these assertive millennials to communicate more easily with their surroundings. Under Speed, Goldstein and Goldfried (2018), assertiveness training is a valuable transdiagnostic intervention. Under the Salter (2002) model, by respecting assertive principles, one can apply self-confident communication strategies in their personal communication models during their career. Salter demarcates four fundamental assertive principles, which we conceptualize in the sampled millennials' communication models:

1) Self-assertion in the sense of promoting one's own opinions and demands, saying what one likes and dislikes, and knowing how to request a favor from others.

2) Standing up for oneself in the sense of not letting oneself be manipulated, knowing how to reject things when they are unwanted, and knowing how to deal with aggression and attacks.

3) Feedback in the sense of knowing how to speak one's criticisms, praise naturally, and accept praise and criticism.

4) Relationship development in the sense of knowing how to listen actively, and establish new relationships and deepen existing ones, including the open expression of personal feelings.

\section{The Pilot Case Study's Methodology and the Specification of Its Empirical Data}

The specification of the empirical data in the pilot case study presented here was performed via mixed method research approach. According to Creswell (2009), quantitative method is based on numbers to claim objectivity; whereas, qualitative method generate theories relying on subjectivity. Objectivity means reaching to the truth while keeping opinions, perceptions, and experiences. Hence, mix method approach employs rigorous quantitative research to assess magnitude of the problem and rigorous qualitative research to explore meaning and understanding of the construct and the context. Mixed method is the intentional integration or combination of the two methods, that is, quantitative and qualitative, to draw on the strengths of each to answer real life research questions. It frames investigation within the philosophical and theoretical positions of both quantitative and qualitative methods. According to Yin (2003), case studies cover specific situations intensively and in depth. Case studies can be 
divided up into teaching and research case studies. In our case, the teaching case study serves for the development of the selected millennials' communication styles, which are primarily educational, because they increase the motivation for the conceptualization of personal communication models. The teaching case study is written in such a way as to motivate the sampled millennials, as they go about conceptualizing their personal communication models, to apply self-confident communication strategies. However, research case studies are more precise than teaching studies. Because of this, for the interactive teaching performed in Professional Consulting and Career Consulting at SU SBA in the 2018/2019 school year, the teaching case study type was replaced with a research pilot case study. The research pilot case study presented here is an alternative to survey-based research in the form of cluster analysis, which we are processing through the evaluation of the empirical data acquired. In our case the empirical data in the research pilot case study was generated via statistical methods in four samples of millennials (a quantitative approach) on the basis of Berne's communication model, interconnected with Silsbee's concept of presence (a qualitative approach). The research contributions by the sampled millennials as respondents provide qualitative empirical data, which the researcher processes through quantitative methods (the arithmetic mean, the coefficient of variation, and the Euclidean metric). Our research goal is to penetrate into Salter's assertiveness principles (2002) in a way that lets them positively influence the application of self-confident communication strategies in the new generation personal communication models.

According to the Center for Generational Kinetics (2016) and Knight (2014), for the first time in a history, two generations will soon be working side by side. Here is an overview of the generations by birth years: iGen, aka the Generation Z: born 1996 and after. Millennials, aka the Generation Y: born 1977 to 1995. According to Maszewski (2016), the new generation, people from generations $\mathrm{Y}$ and $\mathrm{Z}$ treat changes as a desirable element of their lives, like changes and during their work they look for solutions that would enable their efficiency increase. According to Benscik, Juhász and Horváth-Csikos (2016), generation Z and Y, who typically judgethemselves more positive than the older age-groups judged them. They performed better (than the older generations) mainly in the field of IT and in activities which require creativity or innovation. The above-mentioned generations do not like monotony, individual activities, marketing and they also performed poorer in the field of administration. The survey respondents in our research are a sample of students from SU SBA. For the case study presented here, four subsamples of students were produced using deliberate sampling. We chose the number of respondents for each subsample of students separately, based on the defined groups in the two basic sets. Under the Shipman (2014) model, an explanation of the differentiation criteria on whose basis the subsamples of students from the basic sets differ is a prerequisite for our applying deliberate sampling. In our case, it was the gender at SU SBA that served as the sole criteria. In the case study presented here, the subsamples of students were recruited from future graduates of the WOMAN and MEN bachelor's programs and their follow-on master's programs who signed up in the 2018/2019 winter semester at SU SBA for the Professional Consulting subject, and in the summer 2018/2019 semester, those who signed up for the Career Consulting subject. A total of $61(100.0 \%)$ future bachelors at SU SBA were acquired for these two subsamples. $46(75.4 \%)$ of the future bachelors studied the WOMAN, and 15 (24.6\%) of them studied the MEN. Collectively, they provided us with empirical material for conceptualizing assertive principles in personal communication models. (Table 1) 
Table 1: Subsamples of future bachelors at SU SBA 2018/2019

\begin{tabular}{|l|l|l|}
\hline Gender & $\mathbf{6 1}$ & $\mathbf{1 0 0 . 0} \%$ \\
\hline WOMAN & 46 & $75.4 \%$ \\
\hline MEN & 15 & $24.6 \%$ \\
\hline
\end{tabular}

Source: Revue prostor [online]. 27. srpen 2020. [vid. 27. srpen 2020]. Dostupne z: https://revueprostor.cz/107generace-chaosu/

A total of 118 (100.0\%) future engineers were acquired for two subsamples. Out of these, 95 $(80.5 \%)$ of the future engineers studied the WOMAN, and $23(19.5 \%)$ of them studied the MEN. Collectively, they provided empirical material for conceptualizing assertive principles in personal communication models. (Table 2)

Table 2: Subsamples of Future Engineers at SU SBA 2018/2019

\begin{tabular}{|l|l|l|}
\hline Gender & $\mathbf{1 1 8}$ & $\mathbf{1 0 0 . 0} \%$ \\
\hline WOMAN & 95 & $80.5 \%$ \\
\hline MEN & 23 & $19.5 \%$ \\
\hline
\end{tabular}

Source: Revue prostor [online]. 27. srpen 2020. [vid. 27. srpen 2020]. Dostupne z: https://revueprostor.cz/107generace-chaosu/

\subsection{The Research Goal and Research Methodology}

Empirical data on the application of the principles of assertive presence in the personal communication models of the millennials in the four subsamples was acquired using an investigative research method, implemented as a questionnaire survey. The questionnaires' results were then generalized to the main sample after an evaluation of the respondents' stances and preferences.

Our questionnaire was in the form of a single-purpose form with the research goal of acquiring responses from millennials in the four subsamples regarding this basic research question: How can Silsbee's concept of presence be implemented into their personal communication models under Berne? In connection with the implementation of the voices from Silsbee's concept of presence (2018) into Berne's personal communication models (2016), we verify our hypothesis of differing approaches by the millennials in the four subsamples towards the application of Salter's assertiveness principles in the sense of assertive presence depending on their type of gender at SU SBA.

In accord with the Schweigert (2012) model, our hypothesis on a differing approach to the application of assertive presence in personal communication models is operationalized into twelve communication statements, to which the sampled millennials responded. Through their responses, they expressed their personal stances towards assertive presence in communication.

Results were rankings on scales for individual facets of assertive presence. They stated their personal preferences as a number from 0 to 10 , with 0 being the lowest and 10 being the highest degree of personal preference. For calculating the degree of personal preference for assertive presence in communication among the future bachelors and engineers in the 2018/2019 school year at SU SBA, we will apply the arithmetic mean (x) as the sum of all of the values, divided by the number of values. (Tables 3 and 4 )

$x=\left(x_{1}+x_{2}+x_{3}+\ldots+x_{n}\right) / n$ 
Table 3: Assertive Presence in Communication among the Future Bachelors of SU SBA

\begin{tabular}{|c|c|c|}
\hline Self-assertion & WOMAN $=7.8$ & MEN $=7.4$ \\
\hline I assert my opinions and demands! & 8.3 & 6.5 \\
\hline I say what I like and dislike! & 7.5 & 8.1 \\
\hline I know how to ask for favors! & 7.5 & 7.5 \\
\hline Standing up for Oneself & WOMAN $=6.3$ & MEN $=6.5$ \\
\hline I don't let people manipulate me! & 6.3 & 6.5 \\
\hline I know how to politely say no when I don't want something! & 6.6 & 7.2 \\
\hline I can hold my own against aggression and attacks! & 6.0 & 5.9 \\
\hline Feedback & WOMAN = 7.4 & MEN $=7.5$ \\
\hline I know how to express criticism! & 7.1 & 6.4 \\
\hline I know how to praise someone gracefully! & 8.5 & 8.7 \\
\hline I know how to accept praise and criticism! & 6.6 & 7.3 \\
\hline Relationship development & WOMAN $=7.8$ & MEN $=7.8$ \\
\hline I know how to listen actively! & 10.2 & 9.1 \\
\hline I deepen my relationships and establish new ones! & 6.8 & 7.7 \\
\hline I express my feelings openly! & 6.2 & 6.5 \\
\hline
\end{tabular}

Source: own

Table 4: Assertive Presence in Communication among the Future Engineers of SU SBA

\begin{tabular}{|l|l|l|}
\hline Self-assertion & WOMAN $\mathbf{= 7 . 9}$ & MEN $=\mathbf{8 . 3}$ \\
\hline I assert my opinions and demands! & 7.8 & 7.0 \\
\hline I say what I like and dislike! & 8.0 & 10.0 \\
\hline I know how to ask for favors! & 7.9 & 8.0 \\
\hline Standing up for Oneself & WOMAN $=\mathbf{7 . 0}$ & MEN $=\mathbf{7 . 2}$ \\
\hline I don't let people manipulate me! & 6.8 & 7.6 \\
\hline I know how to politely say no when I don't want something! & 7.6 & 7.3 \\
\hline I can hold my own against aggression and attacks! & 6.7 & 6.6 \\
\hline Feedback & WOMAN $=\mathbf{7 . 6}$ & MEN $=\mathbf{7 . 6}$ \\
\hline I know how to express criticism! & 7.5 & 7.0 \\
\hline I know how to praise someone gracefully! & 8.3 & 8.4 \\
\hline I know how to accept praise and criticism! & 7.1 & 7.4 \\
\hline Relationship development & WOMAN $=\mathbf{7 . 8}$ & MEN $=\mathbf{7 . 2}$ \\
\hline I know how to listen actively! & 8.8 & 8.3 \\
\hline I deepen my relationships and establish new ones! & 8.2 & 6.5 \\
\hline I express my feelings openly! & 6.4 & 6.7 \\
\hline
\end{tabular}

Source: own

\section{Cluster Analysis Results and Discussion}

The empirical data from the questionnaire survey was processed and assessed using cluster analysis. This method is described in, for example, Rezanková, Húsek, and Snášel (2009). Cluster analysis belongs among the multi-dimensional statistical methods that group research subjects by similarity into clusters. The research subjects in a given cluster are closer together in their characteristics than the research subjects in other clusters. The foundation for the cluster analysis presented here was taken from the levels of personal preference for assertive presence in communication among selected millennials at SU SBA studying towards gender in the 2018/2019 school year. This is an input data matrix that contains the observed research subjects and their variables. The matrix of similarities and differences in assertive presence among the sampled millennials summarizes the research subjects, which are placed against a backdrop of variability in the characteristics of the variables. 


$$
s=\sqrt{s^{2}}=\sqrt{\frac{1}{n-1} \sum_{i=1}^{n}\left(x_{i}-\bar{x}\right)^{2}}
$$

The most frequently used characteristic of relative variability is the coefficient of variation $\left(\mathrm{v}_{\mathrm{x}}\right)$, which can be used here to compare the variability of the individual variables. The coefficient of variation is defined as the ratio of the standard deviation and the arithmetic mean. If we wish to evaluate how much variability there is in individual variables (the distribution of the likelihood of a random factor), we compare the standard deviation $\left(\mathrm{s}_{\mathrm{x}}\right)$ with the arithmetic mean $(\mathrm{x})$.

$v_{x}=\frac{s_{x}}{\bar{x}} \cdot 100[\%]$

The output from the cluster analysis is a set of clusters of research subjects with similar characteristics (variables), which are obtained through two-dimensional clustering that groups both research subjects and variables. With a view to the goal of conceptualizing the given millennials' personal communication models based on their types of communication strategies for the 2018/2019 school year, non-hierarchical clustering has been used. Nonhierarchical clustering has been used to produce fixed/disjoint clusters, wherein each research subject can be found in one cluster. In our case the research subjects are four subsamples within a sample of millennials from WOMAN and MEN at SU SBA. The non-hierarchical cluster analysis contains a distribution of values for the assertive presence of the four subsamples of millennials as variables. The coefficients of variation are summarized based on the gender at SU SBA into four fixed/disjoint clusters that express the level of assertive presence in the four subsamples of millennials at SU SBA in the 2018/2019 school year. Based on the order of the coefficients of variation, the non-hierarchic cluster analysis follows the level of assertive presence among the sampled millennials. Cronbach's alpha used as a measure of internal consistency or reliability of a psychometric instrument. In cluster 1, relationship development has the highest level among the selected future bachelors WOMAN. Feedback has the second highest level. The willingness to stand up for oneself has the lowest level, along with self-assertion. The distribution of assertive presence in cluster 2 among selected future bachelors MEN corresponds with the level of assertive presence of their WOMAN colleagues. In cluster 3, relationship development dominates among the selected future engineers in WOMAN. The level of self-assertion takes second place. The willingness to stand up for oneself has the lowest level. The distribution of assertive presence in cluster 3 points to a low level of feedback. In cluster 4, the level of self-assertion dominates among the selected future engineers the MEN. The second highest level belongs to relationship development. Their willingness to stand up for oneself has the lowest level, along with feedback. (Table 5) 
Table 5: The Level of assertive presence in the Communication of the Subsamples

\begin{tabular}{|l|l|l|l|l|}
\hline Cluster 1 - WOMAN bac. & $\mathbf{S}$ & $\mathbf{X}$ & $\mathbf{V}_{\mathbf{x}}$ & Level \\
\hline self-assertion & 0.4 & 7.8 & 5.1 & 3. \\
\hline standing up for oneself & 0.2 & 6.3 & 3.2 & 4. \\
\hline feedback & 0.8 & 7.4 & 10.8 & 2. \\
\hline relationship development & 1.8 & 7.8 & 23.1 & 1. \\
\hline Cluster 2 - MEN bac. & $\mathbf{S}$ & $\mathbf{x}$ & $\mathbf{v}_{\mathbf{x}}$ & Level \\
\hline self-assertion & 0.7 & 7.4 & 9.5 & 3. \\
\hline standing up for oneself & 0.5 & 6.5 & 7.7 & 4. \\
\hline feedback & 1.0 & 7.5 & 13.3 & 2. \\
\hline relationship development & 1.1 & 7.8 & 14.1 & 1. \\
\hline Cluster 3 - WOMAN eng. & $\mathbf{S}$ & $\mathbf{x}$ & $\mathbf{v}_{\mathbf{x}}$ & $\mathbf{L e v e l}$ \\
\hline self-assertion & 0.1 & 7.8 & 12.8 & 2. \\
\hline standing up for oneself & 0.4 & 7.0 & 5.7 & 4. \\
\hline feedback & 0.5 & 7.6 & 6.6 & 3. \\
\hline relationship development & 1.0 & 7.8 & 14.1 & 1. \\
\hline Cluster 4 - MEN eng. & $\mathbf{S}$ & $\mathbf{x}$ & $\mathbf{v}_{\mathbf{x}}$ & Level \\
\hline self-assertion & 1.3 & 8.3 & 15.7 & 1. \\
\hline standing up for oneself & 0.4 & 7.2 & 5.6 & 4. \\
\hline feedback & 0.6 & 7.6 & 7.9 & 3. \\
\hline relationship development & 0.8 & 7.2 & 11.1 & 2. \\
\hline
\end{tabular}

Source: own

We evaluated the similarities and dissimilarities in assertive presence in the clusters of the four subsamples of millennials in the 2018/2019 year at SU SBA using the degree of distance, where we count the mutual distances for all $n$ pairs of the research subjects. We have thereby produced a distance matrix for quantitative variable with the application of the euclidean metric $\left(\mathrm{m}_{\mathrm{e}}\right)$, where, $\mathrm{a}$ and $\mathrm{b}$ are vectors with the same number of elements.

$m_{e}(\vec{a}, \vec{b})=\sqrt{\sum_{i=1}^{n}\left(a_{i}-b_{i}\right)^{2}}$

Are the principles off assertive presence in the sampled millennials' communication applied to the same extent? The degree of application in the four fixed/disjoint clusters shows which principles of assertive presence the millennials from the subsamples prefer. Looking along the lines of subjects' gender at SU SBA in the 2018/2019 school year, the highest similarity in the level of application of self-assertion, standing up for oneself, feedback, and relationship development can be found among the future bachelors WOMAN and MEN, whose communication shares a distance indicator of 0 . There are no major differences in the clusters for the future bachelors WOMAN and MEN concerning how they apply the principles of assertive presence. Another cluster of similarity among types of gender at SU SBA, with a distance indicator of 0 , can be found among the future WOMAN and MEN engineers in how they apply the principles of standing up for oneself and feedback. Differences can only be seen in the application of the assertive principle of self-assertion, which is more preferred in communication by the future engineers MEN than those WOMAN. Compared to their MEN colleagues, the future engineers WOMAN more frequently prefer relationship development as a principle of assertive presence in their communication. (Table 6) 
Table 6: Differences and Similarities in Assertive Presence in the Subsamples' Communication

\begin{tabular}{|l|l|l|l|l|}
\hline Principles of Assertive Presence & Cluster 1 & Cluster 2 & $\mathbf{m}_{\mathbf{e}}$ & Level \\
\hline self-assertion & 3. & 3. & 0 & $1 .-4$. \\
\hline standing up for oneself & 4. & 4. & 0 & $1 .-4$. \\
\hline feedback & 2. & 2. & 0 & $1 .-4$. \\
\hline relationship development & 1. & 1. & 0 & $1-4$. \\
\hline Principles of Assertive Presence & Cluster 3 & Cluster 4 & $\mathbf{m}_{\mathbf{e}}$ & Level \\
\hline self-assertion & 2. & 1. & 1 & 3. \\
\hline standing up for oneself & 4. & 4. & 0 & $1 .-2$. \\
\hline feedback & 3. & 3. & 0 & $1 .-2$. \\
\hline relationship development & 1. & 2. & 1.41 & 4. \\
\hline
\end{tabular}

Source: own

What are the similarities and differences in the application of principles of assertive presence in the sampled millennials' communication? The WOMAN and MEN gender at SU SBA differ in the profiles of possibilities for future graduates to apply themselves on the job market. As graduates, the sampled WOMAN millennials will more often go on to careers in the private sector. Their MEN colleagues will primarily go on to careers in the state or public sector. The application of the principles of assertive presence influence the functioning of the psychokinetic anchors through which we conceptualize communication strategies as the foundations of the sampled millennials' models for personal communication. However, these personal communication models lean on differing principles of assertive presence with different functioning of psychokinetic anchors and have different styles of personal communication that we recommend to each of the sampled millennials for the application of self-confident communication strategies on the job market during their professional career. The directive personal communication model relies on feedback and relationship development, which enable the sampled millennials to be outwardly authentic as Persisters, Supporters, and Rebels. The non-directive personal communication model relies on selfassertion and the ability to stand up for oneself, which enable the sampled millennials to remain inwardly authentic as Thinkers, Imaginers, and Harmonizers. Each personal communication style evokes the overuse of certain voices, which are reflected in one's professional career into a particular type of personal communication strategy. What personal communication strategies from the personal directive and non-directive communication model can the sampled millennials apply in their professional careers? Teacher, Contractor, and Guide: The MEN millennials can apply these communication strategies from the directive personal communication model, with overuse of the Teacher, Contractor, and Guide voices, in careers in the state and public sectors. Partner, Investigator, and Reflector: The WOMAN millennials can apply these communication strategies from the non-directive personal communication model, with overuse of the Partner, Investigator, and Reflector voices, in careers in the private sector. (Table 7) 
Table 7: Conceptualized Personal Communication Models for the Application of Communication Strategies

\begin{tabular}{|l|l|l|l|}
\hline The Directive Personal Communication Model \\
\hline Principles & Psychokinetic anchor & Communication Style & Communication Strategy \\
\hline feedback & Persister & Teacher & teaching \\
\hline relationship development & Supporter & Contractor & supervising \\
\hline & Rebel & Guide & guiding \\
\hline \multicolumn{4}{|l|}{ The Non-directive Personal Communication Model } \\
\hline Principles & Psychokinetic anchor & Communicatio Style & Communic Strategy \\
\hline self-assertion & Thinker & Partner & partnering \\
\hline standing up for oneself & Imaginer & Investigator & question-asking \\
\hline & Harmonizer & Reflector & reflection \\
\hline
\end{tabular}

Source: own

When and how can the sampled millennials apply the Master voice in their personal communication in the course of the professional career? The Master voice is a personal communication style through which the millennials in the four subsamples can apply a mastery-oriented communication strategy in both the private sector and the state/public sector. How can the Master communication strategy be useful during one's professional career? Without the overuse of any out of the seven voices, it can be recommended that the Master voice be enabled to serve as an integrating voice wit the use of a combination of the remaining six voices for implementation into a non-directive personal communication model. Self-assertion and the ability to stand up for oneself as principles of assertive presence from the non-directive communication model thus help millennials from our study's subsamples to shape their communication integrity. Under Ceçen-Eroul and Zengel (2009), similar pilot case study was focusing on peer interactions and it emphasized the concept of responsible assertion, which focuses on equal regard for the rights of self and others.

\section{Conclusion}

The results of the research pilot case study presented here point to two designs for personal communication models, the directive personal communication model and the non-directive personal communication model. In what ways are personal communication models specific? In a directive personal communication model, the psychokinetic anchors of the Persister, Supporter, and Reber, relying on the skill of being outwardly authentic, influence the sampled millennials. In a non-directive personal communication model, the psychokinetic anchors of the Thinker, Imaginer, and Harmonizer, relying on the skill of being inwardly authentic, influence the sampled millennials. Over the course of their careers, the skill of being inwardly authentic will produce better conditions for the application of a self-confident communication strategy on the job market and for shaping their communication integrity. The designs of both personal communication models demonstrate the differing personal communication styles of the sampled millennials in regard to the application of self-confident communication strategies on the job market.

Why are we working only with millennials at SU SBA, when generations $Z$ and $Y$ is far broader than this? For the target group at SU SBA mentioned herein, the Professional Consulting and Career Consulting subjects were offered during the 2018/2019 academic year, and the pilot case study was implemented in the framework of these subjects. The personal communication model concepts can only be generalized for our sample of millennials in the 2018/2019 school year at SU SBA.

The future research plan is to time the questions in the questionnaire because personal communication models have to be clarified so that the sampled millennials can correctly 
perceive both their similarities and differences. Only then can they understand what to expect from personal communication models, and only then will each of them be able to apply all seven voices in their communication during their professional career. Assertive presence implemented into self-confident communication strategies will enliven the communication of the sampled millennials WOMAN and MEN, because it will give them the opportunity to recognize its usefulness over the course of their professional career as shapers of the designs for their personal communication models.

\section{Acknowledgement}

This article was created under support of the Ministry of Education, Youth and Sports Czech Republic under the Institutional Support for long-term strategic development of the Silesian University in Opava, Faculty of Business Administration in Karviná in year 2020.

\section{References}

[1] AMES, D. R., 2008. Assertiveness expectancies. How hard people push depends on the consequences they predict. Journal of Personality and Social Psychology, 95(6), 15411557. ISSN 0022-3514.

[2] BENSCIK, A., T. JUHÁSZ and G. HORVÁTH-CSIKOS, 2016. Y and Z generations at workplaces. Journal of Competitiveness, 6(3), 90-106. ISSN 1804-171X.

[3] BERNE, E., 2016. Transactional analysis in psychotherapy. A systematic individual and social psychiatry. Montreal: Pickle Partners Publishing. ISBN 1787200698 9781787200692.

[4] ÇEÇEN-EROUL, A. R. and M. ZENGEL, 2009. The Effectiveness of an Assertiveness Training Programme on Adolescents' Assertiveness Level. Elementary Education, 8(2), 485-492. ISSN 1305-3515.

[5] CRESWELL, J. W., 2009. Research design. Qualitative, quantitative and mixed methods approaches. 3rd ed. Los Angeles: Sage Publications. ISBN 978-1-4129-6557-6.

[6] KNIGHT, R., 2014. Managing people from 5 generations. Harvard Business Review [online]. 28. august 2020 [vid. 28. august 2020]. Dostupné z: https://hbr.org/2014/09/managing-people-from-5-generations.

[7] LAZARUS, R. S., 2015. Fifty years of the research and theory of $R$. S. Lazarus: An analysis of historical and perennial issues. New Jersey: Taylor \& Francis Group. ISBN 9781138991019.

[8] LEE, J. and A. CIFTCI, 2014. Asian international students' socio-cultural adaptation: Influence of multicultural personality, assertiveness, academic self-efficacy, and social support. International Journal of Intercultural Relations. 38(7), 97-105. ISSN 01471767.

[9] MASZEWSKI, F., 2016. Variety of training techniques in the process of generation Z employee development. In: Miltidisciplinary academic conference. Proceedings of MAC$M M E$ 2016. Prague: MAC-MME, pp. 229-236. ISBN 978-80-88085-10-2.

[10] ŘEZANKOVÁ, H. a KOL., 2009. Shluková analýza dat. 2. vyd. Praha: Professional Publishing. ISBN 978-80-86946-81-8.

[11] SALTER, A., 2002. Conditioned reflex therapy. The direct approach to the reconstruction of personality. 50th ed. Gretna LA: Wellness Institute. ISBN 1-5874-0486. 
[12] SILSBEE, D. K., 2018. Presence-based leadership. Complexity practises for clarity, resilience, and results that matter. San Francisco: YG. ISBN 978-0-692-05334-8.

[13] SHIPMAN, M., 2014. The limitations of social research. New York: Routledge. ISBN 0582-31103-9.

[14] SCHMEIDLER, G., 2015. The psychic personality. Psychic exploration. New York: Cosimo Clasics. ISBN 978-1-94452-909-3.

[15] SCHWEIGERT, A. W., 2012. Research methods in psychology. A handbook. 3rd ed. Illinois: Waveland Press. ISBN 9781577667193.

[16] SMITH, M. J., 2003. Řikejte ne súsměvem. Nejoblíbenějši kniha asertivních metod. Praha: NLN. ISBN 80-7106-590-0.

[17] SPEED, B. C., B. L. GOLDSTEIN and M. R. GOLDFRIED, 2018. Assertiveness Training: A Forgotten Evidence-Based Treatment. Clinical Psychology. Science and Practice, 25(1), 1-4. ISSN 0969-5893.

[18] SU OPF (2020). Slezská univerzita Obchodně podnikatelská fakulta v Karviné. Slezská univerzita Obchodně podnikatelská fakulta v Karviné [online]. 27. srpen 2020 [vid. 27. srpen 2020]. Dostupné z: https://www.slu.cz/opf/cz/

[19] THE CENTER FOR GENERATIONAL KINETICS, 2016. Five generations of employees in today's workforce [online]. 28. srpen 2020 [vid. 28. srpen 2020]. Dostupné $\mathrm{z}$ : https://genhq.com/five-generationsof-employees-in-todays-workforce/

[20] VYMĚTAL, J., 2008. Průvodce úspěšnou komunikací. Efektivni komunikace v praxi. Praha: Grada Publishing. ISBN 978-80-247-2614-4.

[21] WOLPE, J., 2012. Tension control for coping end for habit change. In: F. J. McGUIGAN, W. E. SIME and J. M. WALLACE. Stress and Tension Control 2. New York: Pelum Press. pp. 17-27. ISBN 978-1-4613-2803-2.

[22] YIN, R. K., 2003. Case study research: design and methods. Michigan: Sage Publications. ISBN 0-7619-2553-8. 